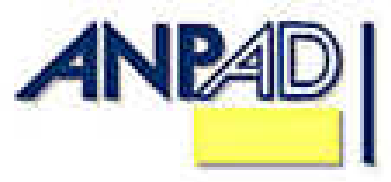

Disponível em

http://www.anpad.org.br/rac

RAC, Curitiba, v. 15, n. 6,

p. 1194, Nov./Dez. 2011

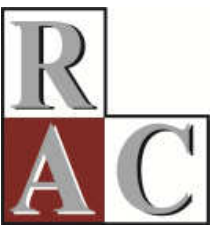

$(c)$ E

\title{
Notas Bibliográficas:
}

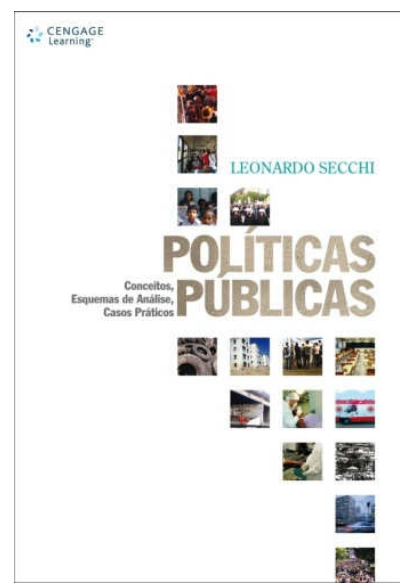

POLÍTICAS

PÚBLICAS:

Conceitos,

Esquemas de

Análise, Casos

Práticos

De Leonardo Secchi. São Paulo: Cengage Learning, 2010. 133p. ISBN 9788522110797.

Utilizando sua bagagem acadêmica nacional e internacional, Leonardo Secchi apresenta a primeira obra didática sobre políticas públicas no Brasil, direcionada principalmente para estudantes e analistas da área. O livro é inovador principalmente na organização do conteúdo, que ao contrário das obras clássicas internacionais, deixa de ter como eixo central o ciclo de política pública para tratar das dimensões conteúdo, tempo, espaço, atores e comportamentos. Essa organização apresenta-se como mais completa, pois aborda tipos de políticas, instituições, atores envolvidos e estilos de políticas.

Nota por Érica Beranger Silva Soares.

UFV, Viçosa/MG, Brasil.

E-mail: ericaberanger@gmail.com 